\title{
Synthesis of Isopropyl Ferulate Using Silica-Immobilized Lipase in an Organic Medium
}

\author{
Ashok Kumar and Shamsher Singh Kanwar \\ Department of Biotechnology, Himachal Pradesh University, Summer Hill, Shimla 171 005, India \\ Correspondence should be addressed to Shamsher Singh Kanwar, kanwarss2000@yahoo.com
}

Received 11 November 2010; Revised 22 January 2011; Accepted 11 February 2011

Academic Editor: Alane Beatriz Vermelho

Copyright (๑) 2011 A. Kumar and S. S. Kanwar. This is an open access article distributed under the Creative Commons Attribution License, which permits unrestricted use, distribution, and reproduction in any medium, provided the original work is properly cited.

\begin{abstract}
Immobilization of lipases has proved to be a useful technique for improving an enzyme's activity in organic solvents. In the present study, the performance of a silica-immobilized lipase was evaluated for the synthesis of isopropyl ferulate in DMSO. The biocatalyst was cross-linked onto the matrix with $1 \%$ glutaraldehyde. The effects of various parameters, molar ratio of ferulic acid to isopropyl alcohol $(25 \mathrm{mM}: 100 \mathrm{mM})$, concentration of biocatalyst $(2.5-20 \mathrm{mg} / \mathrm{mL})$, molecular sieves $(25-250 \mathrm{mg} / \mathrm{mL})$, and various salt ions, were studied consecutively as a function of percent esterification. Immobilized lipase at $25 \mathrm{mg} / \mathrm{mL}$ showed maximum esterification $(\sim 84 \%)$ of ferulic acid and isopropanol at a molar ratio of $25 \mathrm{mM}: 100 \mathrm{mM}$, respectively, in DMSO at $45^{\circ} \mathrm{C}$ in $3 \mathrm{~h}$ under shaking $(150 \mathrm{rpm})$. To overcome the inhibitory effect of water (a byproduct) if any, in the reaction mixture, molecular sieves $(3 \AA \times 1.5 \mathrm{~mm}$; $100 \mathrm{mg} / \mathrm{mL}$ ) were added to the reaction mixture to promote the forward reaction. Salt ions like $\mathrm{Ca}^{2+}, \mathrm{Cd}^{2+}$, and $\mathrm{Fe}^{2+}$ enhanced the activity of immobilized biocatalyst while a few ions like $\mathrm{Co}^{2+}, \mathrm{Zn}^{2+}, \mathrm{Mg}^{2+}, \mathrm{Mn}^{2+}, \mathrm{Al}^{3+}$, and $\mathrm{Na}^{+}$had mild inhibitory effect. Approximately, one third of total decrease in the esterification efficacy was observed after the 5 th repetitive cycle of esterification.
\end{abstract}

\section{Introduction}

In nature, enzymes generally perform their biological functions in aqueous solutions. However, nonaqueous enzymology has found potential applications in enzymatic synthesis as studied by our research group $[1,2]$. From the biotechnological point of view, there are numerous advantages of conducting immobilized biocatalyst promoted enzymatic conversions in organic solvents as opposed to reactions performed in water-based systems. The waterrestricted/organic based reaction system has inherent advantages such as high solubility of most organic compounds in nonaqueous media, ability to carry out new reactions impossible in water because of kinetic or thermodynamic restrictions, and greater stability of enzymes and relative ease of product recovery from organic solvents as compared to water [3]. For various enzymatic reactions, immobilized lipases have been widely studied as an effective tool to achieve hydrolysis/esterification, easy separation of end product(s) and effective separation of biocatalyst. Most proteins are poorly soluble in organic solvents, and it is often necessary to immobilize enzyme onto a suitable porous matrix that provides an increased interfacial surface area, easy separation of catalyst, and its reuse. Also from an industrial point of view, immobilized biocatalysts offer economic incentives of enhanced ease of handling, easy recovery, and reuse relative to nonimmobilized forms [4]. Ferulic acid possesses many potential medical applications that include its use as a scavenger of free radicals or as a protective agent against UV radiation-induced skin damage [5]. Sodium ferulate, the sodium salt of ferulic acid, has been used as medicine in clinical treatment of cardiovascular disease [6] and cerebral thrombosis [7]. Ferulic acid is an antioxidant compound as a result of resonance stabilization of its phenoxy radical by the conjugation of the aromatic nucleus and its extended side chain. This compound is readily isolated from maize waste, where it comprises up to $3 \%$ $(\mathrm{w} / \mathrm{w})$ of total dry mass [8]. Alkyl ester of ferulic acid, such as octyl ferulate, has been observed to have higher antioxidant activity than the acid itself, and the activity of octyl ferulate was reported to be comparable to butyl hydroxyl toluene a lipid soluble antioxidant [9]. Moreover oryzanol, a rice 
bran extract primarily consisting of cycloartenyl ferulate and 24-methylenecycloartenyl ferulate, is widely used in the cosmetic industry as an antioxidant $[10,11]$. Further, sterol ferulate possesses other pharmacological activities such as anti-inflammatory effects [12].

The ester synthesis in organic medium requires careful selection of an organic solvent, optimal relative ratio of reactants, optimal reaction time and temperature, and so forth. An appropriate solvent is always necessary to solublize the substrates and to partition substrates and products in different phases [13]. In some cases, the solvent might be responsible for enzyme's saturation or inhibition. Poor solubility of ferulic acid in most of the solvents such as water and short chain alkanes is responsible for its little use in industry. The solvent is also necessary in case of cosoluble substrates (liquid or solids and liquids) for ester synthesis or trans-esterification $[14,15]$. Water activity associated with dehydrated/immobilized enzyme plays several roles in its structure and functions that included action on enzyme's structure by contribution to all noncovalent bonding, alteration of protein structure by disruption of $\mathrm{H}$ bonds, facilitation of reagent diffusion, and participation in the equilibrium control [16]. The enzyme sometimes might be inactive in dehydrated systems. Thus, it is essential to study the effect of various physical factors as well as solvents to perform the desired esterification in a water-free medium.

In the present study, effects of various reaction parameters on the synthesis of isopropyl ferulate by immobilized lipase have been studied systemically. Isopropyl ferulate is used in the reduction of pharmaceuticals, preparation of antifungal agents, cosmetics and as antioxidant agent and so forth.

\section{Materials and Methods}

2.1. Chemicals. Ferulic acid (4-hydroxy-3-methoxy cinnamic acid) and isopropanol were procured from Merck Schuchardt, Germany and DMSO (Dimethylsulfoxide) from Sigma Aldrich, USA; molecular sieves $(3 \AA \times 1.5 \mathrm{~mm})$ were from E. Merck (India) Ltd.. The commercial lipase, Steapsin, was obtained from Sisco Research Laboratory, Mumbai (India) and the matrix Silica 100-200 mesh was procured from s-d fine Chemicals, Mumbai (India). All these chemicals were used as received.

2.2. Determination of Lipase Activity. The activity of free and immobilized enzyme was measured by a calorimetric method [17]. The reaction mixture contained $80 \mu \mathrm{L}$ of pnitrophenol palmitate (p-NPP) stock solution $(20 \mathrm{mM} \mathrm{p}$ NPP prepared in isopropyl alcohol), the test sample (lipase), and Tris buffer $(0.05 \mathrm{M}, \mathrm{pH} 8.5)$ to make final volume to $3 \mathrm{~mL}$. The reaction mixture was incubated at $45^{\circ} \mathrm{C}$ for $10 \mathrm{~min}$ in a water bath. The reaction was stopped by keeping the reaction mixture at $-20^{\circ} \mathrm{C}$ for $10 \mathrm{~min}$. An appropriate control with a heat-inactivated enzyme ( $5 \mathrm{~min}$ in a boilingwater bath) was included with each assay. The absorbance of p-nitrophenol released was measured at $\mathrm{A}_{410}$. Each of the assays was performed in triplicate, unless otherwise stated, and the mean values were recorded. One unit (1 IU) of lipase activity was defined as the micromoles of p-nitrophenol released per minute by the hydrolysis of p-NPP by $1 \mathrm{~mL}$ of soluble enzyme or $1 \mathrm{~g}$ of silica bound enzyme (weight of matrix included) at $45^{\circ} \mathrm{C}$ under assay conditions. All the additives including buffer were preincubated for a short period $(3 \mathrm{~min})$ before the enzyme was added to start the reaction. The specific activity was expressed as micromoles of the p-nitrophenol released per min by $1 \mathrm{mg}$ of protein.

2.3. Determination of Protein Content. Protein concentration was determined using bovine serum albumin as a standard [18]. The silica-immobilized lipase was prepared in bulk for subsequent use.

2.4. Immobilization of Enzyme onto Silica. The matrix was washed three times with Tris buffer $0.05 \mathrm{M}(\mathrm{pH}$ 8.5) to remove any type of the soluble impurities. The silica $(4 \mathrm{~g})$, pre-equilibrated in an excess volume of Tris buffer (0.05 M, pH 8.5) [19], was incubated with commercial lipase "Steapsin" (5.32 IU/mL and $18.2 \mathrm{mg} / \mathrm{mL}$ protein) at $8^{\circ} \mathrm{C}$ overnight. The volume of the supernatant, amount of unbound protein, and the lipase activity were estimated. The weight of the enzyme-incubated matrix was determined and the bound lipase activity was assayed using $20 \mathrm{mg}$ of matrix/reaction volume $(2 \mathrm{~mL})$ unless stated otherwise. The bound protein in the matrix was determined by subtraction of the unbound protein in the supernatant from the total protein used for immobilization [20]. Hydrolytic properties of the silica-immobilized lipase were evaluated under various reaction conditions for the synthesis of isopropyl ferulate in DMSO. The silica-bound biocatalyst was treated with a crosslinking agent (glutaraldehyde; $1 \%, \mathrm{v} / \mathrm{v}$ ) so as to retain its activity for a longer period of time [21-23].

\subsection{Effect of Buffer pH and Temperature on Hydrolytic Activity} of Silica-Bound Lipase. The reaction variables such as buffer $\mathrm{pH}(7.0,7.5,8.0,8.5,9.0$, and 9.5) and reaction temperature $\left(30\right.$ to $60^{\circ} \mathrm{C}$ ) on the catalytic potential of the matrix-bound lipase were studied by incubating the immobilized lipase $(20 \mathrm{mg} /$ reaction volume of $2 \mathrm{~mL}$ ) separately in glass tubes containing Tris buffer adjusted to the specified $\mathrm{pH}(0.05 \mathrm{M}$ and $0.1 \% \mathrm{w} / \mathrm{v}$ gum acacia). The lipase activity was assayed after 10 min of incubation at $37^{\circ} \mathrm{C}$. The buffer $\mathrm{pH}$ that was found to be optimum to hydrolytic reaction was further selected to study the effect of reaction temperature on hydrolysis of p-NPP.

2.6. Esterification of Isopropyl Alcohol and Ferulic Acid. Isopropyl ferulate synthesis was performed by using isopropanol $(100 \mathrm{mM})$, ferulic acid $(25 \mathrm{~mm})$, and silica-bound lipase ( $20 \mathrm{mg}, \sim 5.3 \mathrm{IU}$ ) taken in $2.0 \mathrm{~mL}$ of DMSO in Teflonlined glass vial ( $5 \mathrm{~mL}$ capacity). The reaction was performed at $45^{\circ} \mathrm{C}$ for $3 \mathrm{~h}$ along with buffer-activated silica as a control under shaking $(150 \mathrm{rev} / \mathrm{min})$. Each of the reactions was performed in duplicate, and average values were calculated. Samples $(10 \mu \mathrm{L})$ were withdrawn at intervals and analyzed 


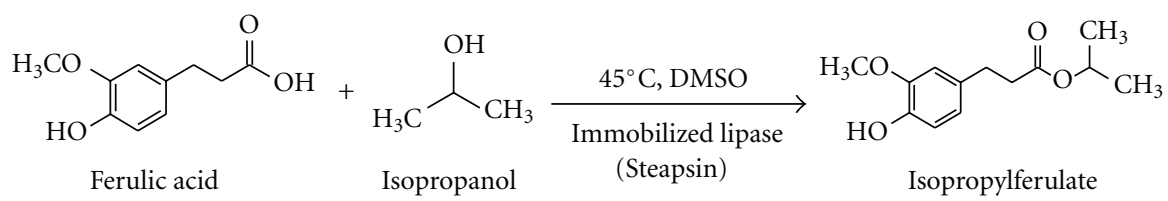

by gas liquid chromatography (GLC) for the presence of isopropyl ferulate.

2.7. Analysis of Isopropyl Ferulate by GLC. The isopropyl ferulate produced in the reaction cocktail was analyzed by GLC equipped with a flame ionization detector and a column (10\% SE-30 Chrom WHP, 2 meter length, mesh size 80-100, internal diameter $1 / 8$ inches, maximum temperature limit $300^{\circ} \mathrm{C}$; Netel Chromatograph, Thane, India). Nitrogen was used as a carrier gas $\left(30 \mathrm{~cm}^{3} / \mathrm{min}\right)$. The injector was set at $260^{\circ} \mathrm{C}$, detector at $270^{\circ} \mathrm{C}$, and the column/oven temperature at $250^{\circ} \mathrm{C}$. The sample size for the GLC analysis was $2 \mu \mathrm{L}$.

2.8. Optimization of Reaction Parameters for Synthesis of Isopropyl Ferulate. The effect(s) of various factors such as reaction time, relative molar concentration of reactants, amount of molecular sieves, and reaction temperature on the synthesis of isopropyl ferulate was separately evaluated. All esterification reactions were performed in triplicate using $20 \mathrm{mg}$ of silica-bound lipase per reaction volume $(2 \mathrm{~mL})$ at $45^{\circ} \mathrm{C}$ under shaking ( $150 \mathrm{rev} / \mathrm{min}$ ). The concentration of ferulic acid and isopropanol was varied one at a time by keeping the other one constant. The isopropanol concentration was kept at $100 \mathrm{mM}$, and ferulic acid concentration was varied as $25,50,75$, and $100 \mathrm{mM}$. The reaction was carried out for $15 \mathrm{~h}$ at $45^{\circ} \mathrm{C}$ under shaking. Further esterification reactions were carried out at optimized molar concentrations of ferulic acid and ethanol (i.e., $100 \mathrm{mM}$ isopropanol and $25 \mathrm{mM}$ ferulic acid in DMSO).

The solvent phase $(2 \mu \mathrm{L})$ of reaction mixture was periodically ( $2 \mathrm{~h}$ intervals) sampled and analyzed by GLC for the presence of isopropyl ferulate. The optimized reaction time was adopted in the subsequent experiment. The synthesis of isopropyl ferulate was performed by placing varying amounts of the immobilized biocatalyst $(2.5-17.5 \mathrm{mg} / \mathrm{mL}$ in duplicates) in $2 \mathrm{~mL}$ of reaction mixture containing $25 \mathrm{mM}$ of ferulic acid and $100 \mathrm{mM}$ of isopropanol in DMSO at $45^{\circ} \mathrm{C}$ for $3 \mathrm{~h}$ under shaking $(150 \mathrm{rev} / \mathrm{min})$. The effect of reaction temperature $\left(30,35,40,45,50,55\right.$, and $\left.60^{\circ} \mathrm{C}\right)$ on the synthesis of isopropyl ferulate was also studied by incubating the reaction mixture containing isopropanol:ferulic acid (100 mM: $25 \mathrm{mM})$ in DMSO and silica-immobilized lipase $(10 \mathrm{mg} / \mathrm{mL})$ at each of the selected temperatures for $3 \mathrm{~h}$ under shaking. To study the possible inhibitory role of water that is produced as a byproduct in the reaction mixture during the esterification reaction, molecular sieves (25$250 \mathrm{mg} / \mathrm{mL}$ ) were added to reaction mixture containing $10 \mathrm{mg} / \mathrm{mL}$ of biocatalyst. The esterification was achieved at $45^{\circ} \mathrm{C}$ for $3 \mathrm{~h}$, and isopropyl ferulate formed in each case was determined. Effect of various salt ions ( $1 \mathrm{mM})$ on the esterification activity of the bound lipase was assessed by pretreatment of immobilized enzyme with each of the selected salt ions $\left(\mathrm{Fe}^{3+}, \mathrm{Al}^{3+}, \mathrm{NH}_{4}^{+}, \mathrm{Ca}^{2+}, \mathrm{Co}^{2+}, \mathrm{Mg}^{2+}\right.$, $\mathrm{Hg}^{2+}, \mathrm{Ba}^{2+}, \mathrm{Cd}^{3+}, \mathrm{Zn}^{2+}$, and $\mathrm{Mn}^{2+}$ ) for $1 \mathrm{~h}$ at $45^{\circ} \mathrm{C}$ under shaking. Thereafter, the silica-bound lipase was spun down $(10,000 \times \mathrm{g}$ for $2 \mathrm{~min}$ at room temperature), and the buffer containing salt ion(s) was completely decanted by inversion. The sedimented bound enzyme was washed in DMSO $(2 \mathrm{~mL})$ once and spun down again to perform the esterification as above. The synthesis of isopropyl ferulate was recorded thereafter by GLC.

2.9. Cumulative Effect of Molecular Sieves and Varying Concentrations of Selected Salt Ions ( $\mathrm{Cd}^{2+}, \mathrm{Ca}^{2+}$, and $\left.\mathrm{Fe}^{2+}\right)$ on Esterification. The optimized concentration of molecular sieves that enhanced the esterification and the salt ions $\left(\mathrm{Cd}^{2+}, \mathrm{Ca}^{2+}\right.$, and $\left.\mathrm{Fe}^{2+}\right)$ promoting the synthesis of isopropyl ferulate was selected for further studies. The immobilized biocatalyst $(12.5 \mathrm{mg} / \mathrm{mL})$ separately pretreated with the salt ions $\left(\mathrm{Cd}^{2+}, \mathrm{Ca}^{2+}\right.$, or $\left.\mathrm{Fe}^{2+}\right)$ at 1,3 , or $5 \mathrm{mM}$ for $1 \mathrm{~h}$ at $45^{\circ} \mathrm{C}(0.05 \mathrm{M}$ Tris buffer, $\mathrm{pH} 8.5)$ was used to catalyze the esterification of ferulic acid $(25 \mathrm{mM})$ and isopropanol $(100 \mathrm{mM})$ in DMSO.

2.10. Reusability of the Immobilized Lipase in Continuous Cycles of Esterification. The immobilized lipase exposed to $3 \mathrm{mM}$ of $\mathrm{Ca}^{2+}$ ions (0.05 M Tris buffer, $\mathrm{pH} 8.5$ ) was used for the synthesis of isopropyl ferulate in DMSO, repetitively up to 8 cycles of $3 \mathrm{~h}$ each at $45^{\circ} \mathrm{C}$ under shaking. After the first cycle of esterification, the biocatalyst was recovered (by centrifuging and decanting the reaction mixture), and the washed biocatalyst $(25 \mathrm{mg}$ ) was added to $2 \mathrm{~mL}$ of fresh reaction mixture for the synthesis of isopropyl ferulate as above. The silica-bound biocatalyst was recovered, washed, and reused for the next cycle of ester synthesis. The reaction system contained $25 \mathrm{mM}$ ferulic acid and $100 \mathrm{mM}$ isopropanol, and the reaction was carried out under optimized conditions.

2.11. Statistical Analysis. An analysis of variance (ANOVA) was conducted on the data obtained in each of the experimental studies with statistical package Assistat version7.4 beta 2010" for comparison of mean responses (mean standard error) and to determine the statistical significance. The standard deviation (SD) about the mean for each of the regimens was depicted in the figures. 


\section{Results and Discussion}

3.1. Immobilization of the Commercial Lipase. The commercial lipase Steapsin was optimally immobilized onto silica that retained $95.3 \%$ of total protein used for immobilization. The activity of free lipase was found to be $5.6 \mathrm{IU} / \mathrm{mL}$. After immobilization onto silica, the bound lipase exhibited 5.3 IU/mL activity. Thus, following immobilization, the silica matrix retained approximately $98 \%$ of originally used lipase as reflected by the hydrolytic activity of the bound biocatalyst. In a previous study, lipase immobilized onto a poly (MAc-co-DMA-cl-MBAm) hydrogel showed approximately $94 \%$ binding of lipase. The hydrogel-bound lipase also gave a higher yield for both hydrolysis of p-NPP and esterification for the synthesis of isopropyl myristate as compared to other polymers [24].

The hydrolytic activity of the silica-bound lipase was recorded at each of the selected $\mathrm{pH}$ of the Tris buffer, namely, 7.0 (2.16 IU/mL), 7.5 (3.08 IU/mL), 8.0 (4.91 IU/mL), 8.5 (5.84 IU/mL), $9.0(5.44 \mathrm{IU} / \mathrm{mL})$, and $9.5(4.11 \mathrm{IU} / \mathrm{mL})$. At $\mathrm{pH} 8.5$ and 9.0, the observed activities were significantly higher than those obtained at other $\mathrm{pH}$ values $(P<.05)$. Among the selected temperature of $30^{\circ} \mathrm{C}(0.81 \mathrm{IU} / \mathrm{mL}), 35^{\circ} \mathrm{C}$ (3.94 IU/mL), $40^{\circ} \mathrm{C}(4.77 \mathrm{IU} / \mathrm{mL}), 45^{\circ} \mathrm{C}(5.80 \mathrm{IU} / \mathrm{mL}), 50^{\circ} \mathrm{C}$ $(5.77 \mathrm{IU} / \mathrm{mL}), 55^{\circ} \mathrm{C}(4.78 \mathrm{IU} / \mathrm{mL})$, and $60^{\circ} \mathrm{C}(4.12 \mathrm{IU} / \mathrm{mL})$ at which the hydrolytic activity of bound lipase towards pNPP was studied, the silica-bound lipase showed comparable activities at 45 and $50^{\circ} \mathrm{C}$ that were significantly higher than those recorded at other reaction temperatures. Thus, a $\mathrm{pH}$ 8.5 and temperature $45^{\circ} \mathrm{C}$ was considered optimum for the activity of the bound lipase.

\subsection{Effect of Physicochemical Parameters on Esterification.} The exploitation of commercial applications of lipases for preparing value-added specialty products from lipids by esterification/transesterification depends on understanding and controlling reaction selectivity towards different substrates [25]. Various features of reaction selectivity of lipases are modulated by exogenous factors such as type of organic solvent, choice of cosubstrates/reactants, water activity, $\mathrm{pH}$, temperature, and immobilization [26-29]. The optimum values of temperature, $\mathrm{pH}$, time of reaction, and molar concentration of reactants must be determined in each case to carry out the desired esterification reaction expecting higher yield [30]. In the present study, concentration of the biocatalyst, molecular sieves, and some of the selected salt ion(s) showed cumulative effect to enhance the yield of isopropyl ferulate in the reaction mixture.

Kinetics of immobilized lipase catalyzed synthesis of isopropyl ferulate was studied for $15 \mathrm{~h}$ at $45^{\circ} \mathrm{C}$ in DMSO under continuous shaking at $150 \mathrm{rpm}$. The isopropyl ferulate was formed with a maximum conversion rate of approximately $83.6 \%$ within a short period of $3 \mathrm{~h}$. Thus, in the subsequent experiments a reaction time of $3 \mathrm{~h}$ at $45^{\circ} \mathrm{C}$ for immobilized lipase was considered optimum for the synthesis of isopropyl ferulate. The reaction temperature often has an important effect on the physical state of substrate dispersion also. Higher temperature and liquefaction tend to make the substrate more diffusible and hence easily acceptable to the

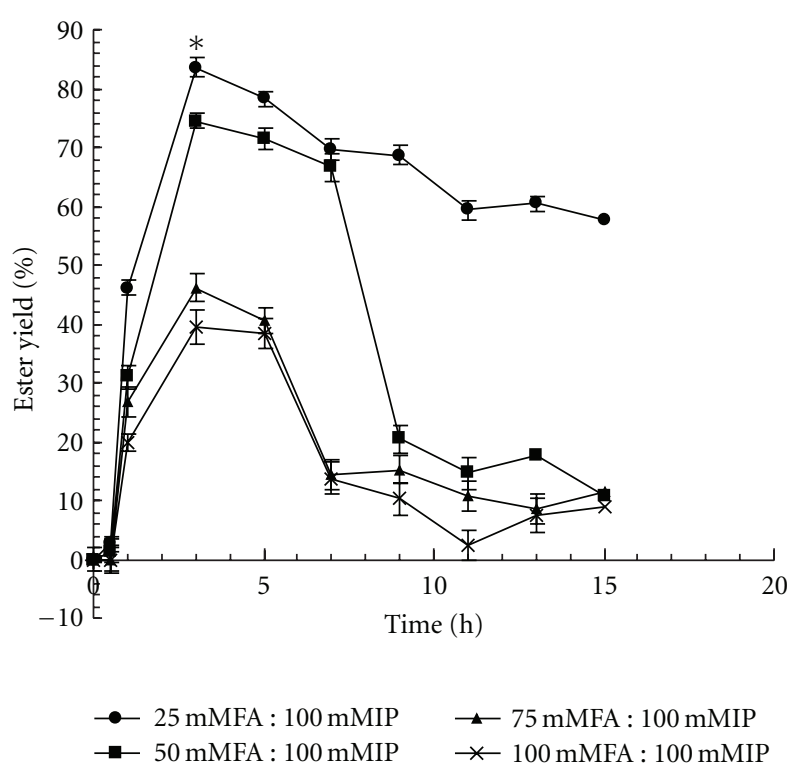

Figure 1: Effect of reaction time on the yield of isopropyl ferulate. The esterification was performed for $15 \mathrm{~h}$ at $45^{\circ} \mathrm{C}$ using $100 \mathrm{mM}$ isopropanol (IP) and $25 \mathrm{mM}$ ferulic acid (FA) in DMSO under shaking. The ester yield was significantly higher $(*)$ when FA: IP was used at $25 \mathrm{mM}: 100 \mathrm{mM}$ than ester yield obtained at $75 \mathrm{mM}: 100 \mathrm{mM}$ and $100 \mathrm{mM}: 100 \mathrm{mM}$, respectively, under identical reaction conditions.

enzyme [31]. But ferulic acid is unstable at high temperatures where it undergoes oxidation [32]. The concentrations of ferulic acid and ethanol were varied one at a time keeping the other one constant. The concentration of isopropanol was kept $100 \mathrm{mM}$ and ferulic acid concentration was varied as 25 , 50,75 , and $100 \mathrm{mM}$. The reaction was carried out for $15 \mathrm{~h}$ at $45^{\circ} \mathrm{C}$ under shaking. The maximum ester synthesis was recorded when concentration of ferulic acid and isopropanol was $25 \mathrm{mM}: 100 \mathrm{mM}$. A subsequent significant decrease $(P<.05)$ in the ester formation with an increase in the concentration of ferulic acid up to $100 \mathrm{mM}$ was observed (Figure 1). On the basis of these observations, further esterification reactions were carried out at optimized molar concentrations of ferulic acid and isopropanol $(25 \mathrm{mM}$ and $100 \mathrm{mM}$, resp.). In a recent study, the synthesis of ethyl ferulate was carried out by using equimolar mixture of ethanol and ferulic acid using celite-bound lipase at $45^{\circ} \mathrm{C}$ [24]. The synthesis of isopropyl ferulate was performed by placing varying amounts of the immobilized lipase (2.5$20 \mathrm{mg} / \mathrm{mL}$ ) in $2 \mathrm{~mL}$ of a reaction mixture containing $100 \mathrm{mM}$ isopropanol and $25 \mathrm{mM}$ ferulic acid in DMSO at $45^{\circ} \mathrm{C}$ for $3 \mathrm{~h}$ under shaking (150 rpm). Approximately, $80 \%$ yield of isopropyl ferulate with $12.5 \mathrm{mg} / \mathrm{mL}$ immobilized biocatalyst was recorded (Figure 2 ). In a recent study, $10 \mathrm{mg} / \mathrm{mL}$ of celitebound lipase was found to give an optimum yield of ethyl ferulate in DMSO [24]. Enzyme concentration is known to influence esterification reaction. Temperature had an important effect on the physical state of substrate dispersion also. Higher temperature and liquefaction tend to make the substrate more diffusible and hence easily acceptable to the 


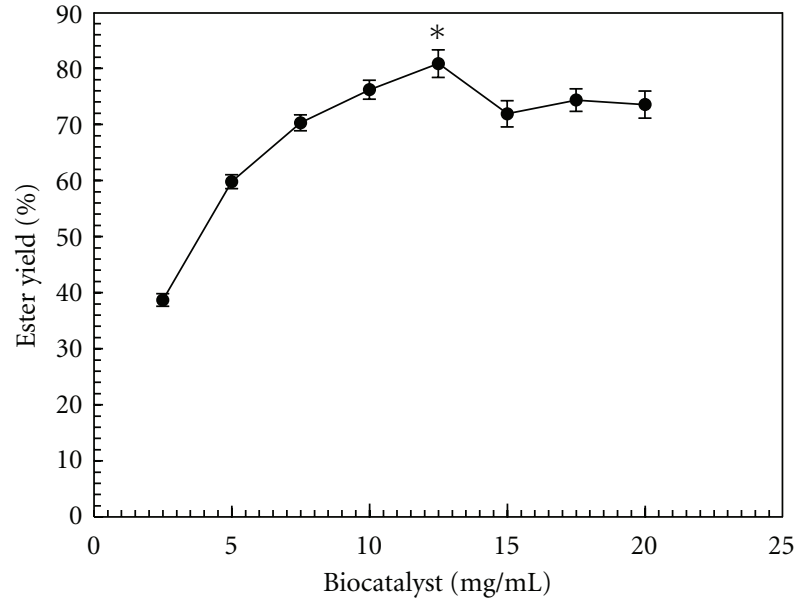

Figure 2: Effect of silica-bound biocatalyst concentration on synthesis of isopropyl ferulate. The esterification was performed for $3 \mathrm{~h}$ at $45^{\circ} \mathrm{C}$ using isopropanol $(100 \mathrm{mM})$ and ferulic acid $(25 \mathrm{mM})$ in DMSO under shaking. The ester yield was significantly higher (*) when $12.5 \mathrm{mg} / \mathrm{mL}$ of silica-bound biocatalyst was used $(P<$ $.05)$.

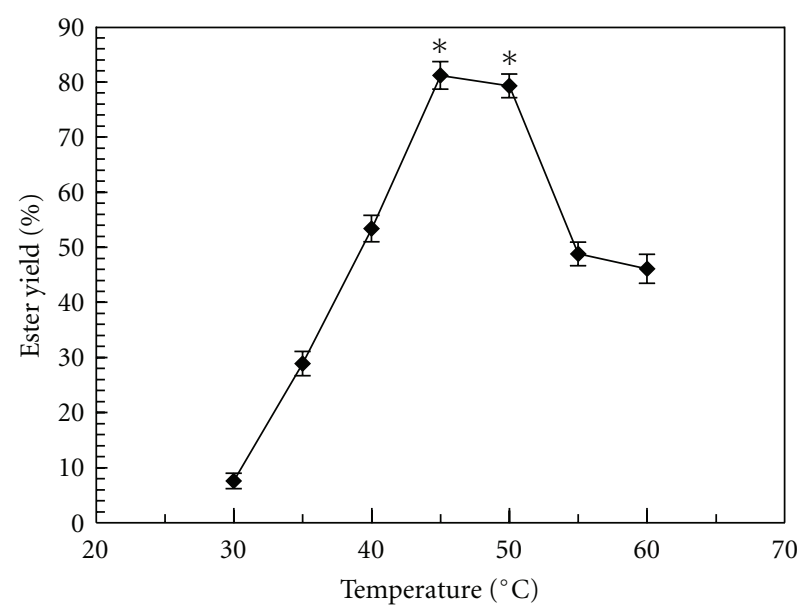

FIGURE 3: Effect of temperature on the synthesis of isopropyl ferulate. The esterification was performed for $3 \mathrm{~h}$ at specified temperature using isopropanol $(100 \mathrm{mM})$ and ferulic acid $(25 \mathrm{mM})$ in DMSO under shaking. A significantly higher $(*)$ yield of isopropyl ferulate was recorded at 45 and $50^{\circ} \mathrm{C}$ in comparison to the other reaction temperatures using silica-bound biocatalyst $(P<$ $.05)$.

enzyme [33]. In a previous study, lipase immobilized onto a poly (MAc-co-DMA-cl-MBAm) hydrogel showed higher yield for both hydrolysis and esterification for the synthesis of isopropyl myristate as compared to other polymers [34].

The silica-immobilized lipase performed the synthesis of isopropyl ferulate $(81.2 \mathrm{mM})$ much efficiently at $45^{\circ} \mathrm{C}$ (Figure 3). The optimal synthesis of ethyl ferulate using celite-bound lipase was also observed at the same temperature [24], as the increase above $30^{\circ} \mathrm{C}$ showed a corresponding increase in the rate of esterification and maximum percentage yield was observed at $45^{\circ} \mathrm{C}$. However, increase

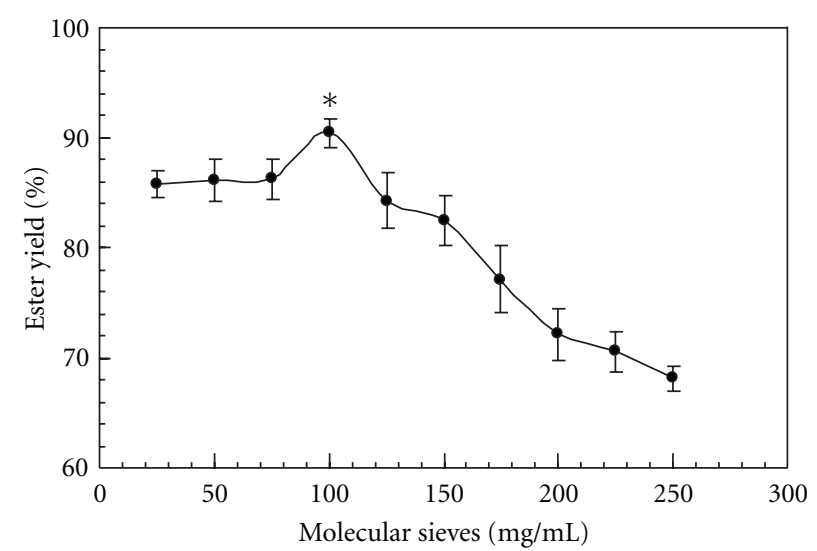

Figure 4: Effect of molecular sieves on synthesis of isopropyl ferulate. The esterification was performed for $3 \mathrm{~h}$ at $45^{\circ} \mathrm{C}$ using isopropanol $(100 \mathrm{mM})$ and ferulic acid $(25 \mathrm{mM})$ in DMSO under shaking. A significantly higher $(*)$ yield of isopropyl ferulate was recorded when molecular sieves were added to the reaction cocktail at $100 \mathrm{mg} / \mathrm{mL}$ concentration in compassion to the yield recorded at $175-250 \mathrm{mg} / \mathrm{mL}$ of molecular sieves using silica-bound biocatalyst $(P<.05)$.

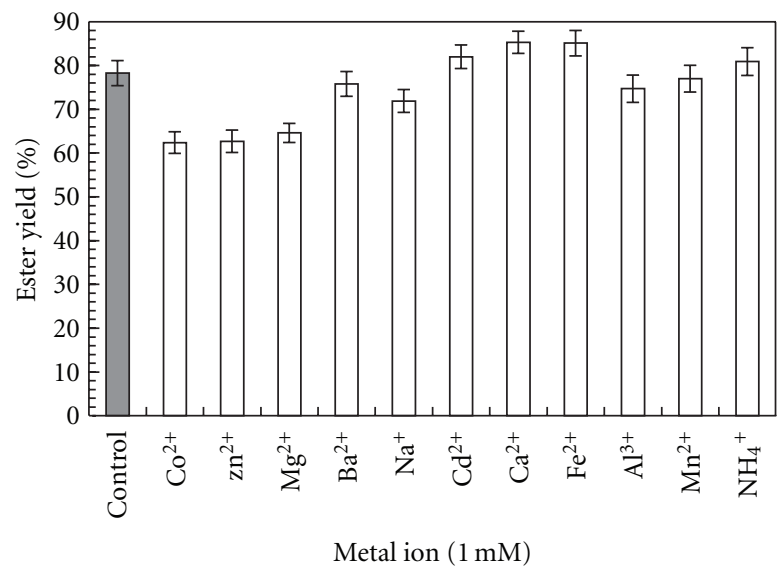

Figure 5: Effect of salt ions on the synthesis of isopropyl ferulate. The silica-bound lipase pre-exposed to the selected salt ions ( $1 \mathrm{mM}$ ) for $1 \mathrm{~h}$ at $45^{\circ} \mathrm{C}$ was used to achieve esterification of isopropanol and ferulic acid (100 mM:25 mM) in DMSO under shaking in $3 \mathrm{~h}$.

in temperature beyond $45^{\circ} \mathrm{C}$ resulted in a decline in the ester synthesis. With increasing concentration of molecular sieves $(25 \mathrm{mg} / \mathrm{mL}$ to $250 \mathrm{mg} / \mathrm{mL})$, the optimal yield of isopropyl ferulate $(\sim 90 \mathrm{mM})$ was noticed when $100 \mathrm{mg} / \mathrm{mL}$ of molecular sieves were used in the reaction mixture. A further increase of the concentration of the molecular sieves $(>100 \mathrm{mg} / \mathrm{mL})$ resulted in a gradual but significant decrease in synthesis of ester (Figure 4). Esterification of isopropanol and ferulic acid by silica-immobilized lipase in the presence of molecular sieves and certain salt ions brought about an improvement in the yield of isopropyl ferulate. Water that is produced as a byproduct of the esterification reactions performed by biocatalysts in organic media has several adverse effects on the reaction and enzyme 


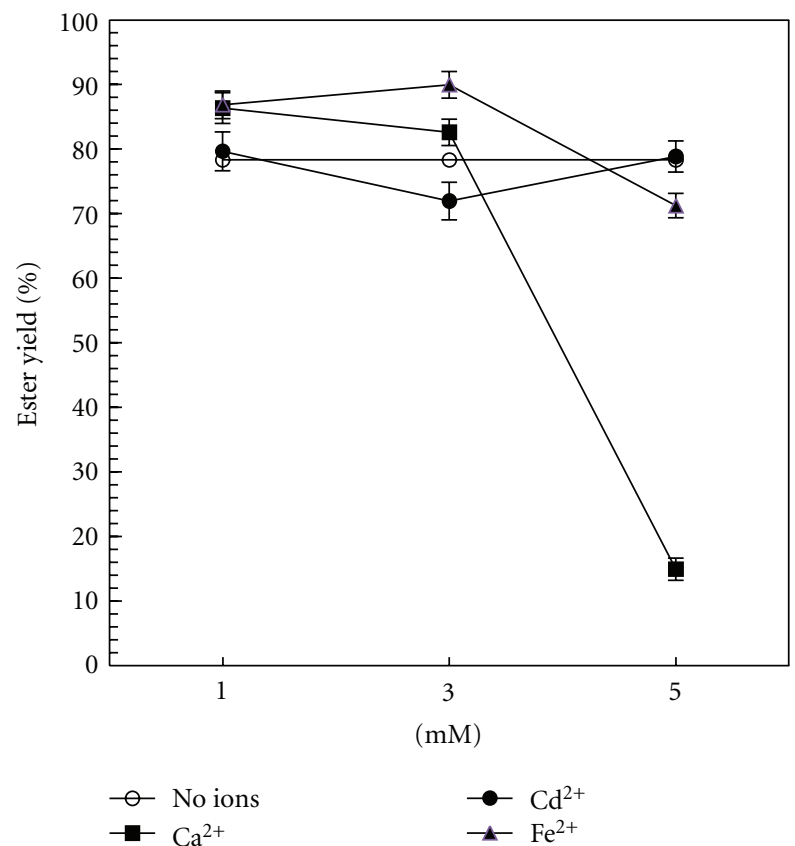

FIGURE 6: Effect of selected metal ions on the synthesis of isopropyl ferulate. The silica-bound lipase pre-exposed to the selected salt ions prepared in Tris buffer $(0.05 \mathrm{M} ; \mathrm{pH} 8.5)$ for $1 \mathrm{~h}$ at $45^{\circ} \mathrm{C}$ was used to achieve esterification of isopropanol and ferulic acid $(100 \mathrm{mM}: 25 \mathrm{mM})$ in DMSO at $45^{\circ} \mathrm{C}$ under shaking in $3 \mathrm{~h}$.

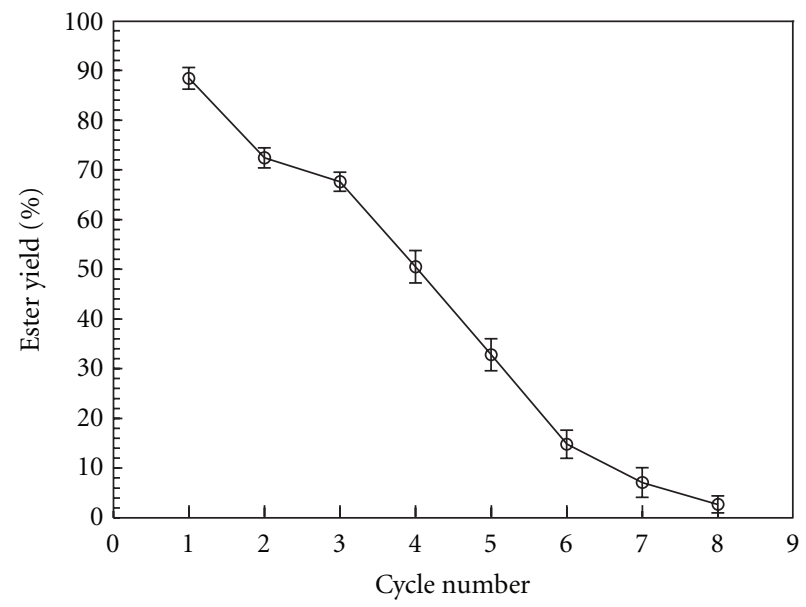

FIGURE 7: Repetitive use of immobilized biocatalyst for the synthesis of isopropyl ferulate. The esterification was performed for $3 \mathrm{~h}$ at $45^{\circ} \mathrm{C}$ using isopropanol $(100 \mathrm{mM})$ and ferulic acid $(25 \mathrm{mM})$ in DMSO under shaking. A significant decline in the yield of isopropyl ferulate was recorded after each cycle of repetitive esterification after the 1st cycle of repetitive esterification in the presence of molecular sieves $(100 \mathrm{mg} / \mathrm{mL} ; P<.05)$.

activity/performance. Esterification is generally a waterlimited reaction [35], and excess of water activity inhibits the forward catalytic reaction in water restricted/organic medium. The formation of water also causes aggregation of support particles resulting in a decrease in the rate of enzyme activity. Esterification of isopropyl alcohol and ferulic acid by silica-immobilized lipase in the absence of a water scavenger/molecular sieves exhibited approximately $84 \%$ esterification. However, presence of molecular sieves in the reaction cocktail significantly improved the isopropyl yield up to $90 \%$ that was approximately $48 \%$ more than that recorded for the synthesis of ethyl ferulate $(68 \mathrm{mM})$ in DMSO as reported recently [24]. The addition of molecular sieves usually improved the equilibrium conversion $[24,36]$, yet in many cases negative effects such as the formation of diester and degradation of unstable substrates have also been reported $[37,38] . \mathrm{Fe}^{2+}, \mathrm{Ca}^{2+}$, and $\mathrm{Cd}^{2+}$ enhanced the activity of immobilized lipase while $\mathrm{Co}^{2+}, \mathrm{Zn}^{2+} \mathrm{Mg}^{2+}$, and $\mathrm{Mn}^{2+}$ showed an inhibitory effect on the catalytic behavior of enzyme. $\mathrm{NH}_{4}{ }^{+}$and $\mathrm{Ba}^{2+}$ ions did not show any significant effect on the esterification activity of immobilized lipase. The immobilized enzyme presented a particular affinity for certain salt ions like $\mathrm{Fe}^{2+}, \mathrm{Ca}^{2+}$ and $\mathrm{Cd}^{2+}$ and the conversion of the reactants into isopropyl ferulate approached to $85.3 \%$ (Figure 5). In a previous study on Burkholderia multivorans V2, the exposure to salt ions such as $\mathrm{Ca}^{2+}, \mathrm{Mg}^{2+}$ and $\mathrm{Mn}^{2+}$ stimulated the lipase activity while $\mathrm{Cu}^{2+} \mathrm{Fe}^{2+}$ and $\mathrm{Zn}^{2+}$ ions antagonized the biocatalytic potential of lipase [30]. In a recent study, $\mathrm{Co}^{2+}, \mathrm{Ba}^{2+}$, and $\mathrm{Pb}^{2+}$ ions enhanced while $\mathrm{Hg}^{2+}, \mathrm{Ca}^{2+}$, and $\mathrm{NH}_{4}{ }^{+}$antagonized the catalytic activity of a celite-bound commercial lipase for the synthesis of ethyl ferulate [24]. The inhibitory nature of transition metals has been thought to be due to interaction of ions with charged side chain groups of surface amino acids, thus influencing the conformation and stability of the enzyme [39]. However, in the present study, $\mathrm{Fe}^{2+}$ ions were found to have good stimulatory effect on the synthesis of isopropyl ferulate. Previously, the $\mathrm{Fe}^{2+}$ ions have been found to have an antagonistic effect on esterification [30] that is in contradiction to the above observation. The $\mathrm{Al}^{3+}$ and $\mathrm{Co}^{2+}$ had moderate inhibitory effect on the lipase activity. The stimulatory effect of $\mathrm{Mg}^{2+}$ and $\mathrm{Ca}^{2+}$ on lipase activity had been reported by several researchers and has been attributed to structural alterations in the catalytic site of the lipase rather than any catalytic role assigned to these ions [40]. The immobilized enzyme was pretreated separately with each of the three salt ions $\left(\mathrm{Fe}^{2+}, \mathrm{Ca}^{2+}\right.$, and $\left.\mathrm{Cd}^{2+}\right)$ at concentration 1,3 , and $5 \mathrm{mM}$. An increase in the concentration of $\mathrm{Fe}^{2+}$ up to $5 \mathrm{mM}$ showed a sharp decrease in the ester synthesis while $\mathrm{Ca}^{2+}$ caused a rise in isopropyl ferulate synthesis at the concentration $3 \mathrm{mM}$ and above. In case of $\mathrm{Cd}^{2+}$ ions, an increase in the concentration up to $5 \mathrm{mM}$ did not exhibit any modulation in ester formation (Figure 6). Previously, $\mathrm{Cd}^{2+}$ ions have been found to have an inhibitory role in the synthesis of ethyl ferulate [24].

3.3. Reusability of Immobilized Biocatalyst for Ester Synthesis. It was observed that the silica-immobilized lipase catalyzed the esterification appreciably for the first three cycles, and, thereafter, its activity started to decline significantly $(P<$ .05 ). The silica-bound lipase yielded $14.8 \mathrm{mM}$ of isopropyl ferulate at $45^{\circ} \mathrm{C}$ after the 6th cycle of esterification (Figure 7). Thus, about $33 \%$ decrease in the esterification efficacy of the silica-bound biocatalyst was observed after the 5 th repetitive 
cycle of esterification. The immobilization onto inert and nonsoluble matrix like silica aided in reusability of lipase and its easy recovery too; however, the leaching of the bound lipase during repetitive reuse seems to be one of the drawbacks of such a matrix.

\section{Conclusion}

In this work, we demonstrated the synthesis of a medically important ester isopropyl ferulate in a waterrestricted medium by a silica-immobilized commercial lipase. Besides, the isopropyl ferulate being produced at high level ( $\sim 90 \%$ yield) in a short period of time $(3 \mathrm{~h})$, the enzyme retained good activity and stability after repetitive use and a remarkable stability towards organic solvent DMSO. These results, especially the cumulative effect of various parameters like temperature, $\mathrm{pH}$, reaction time, molar ratio of reactants, and removal of byproduct of esterification by molecular sieves, vastly improved the yield of the isopropyl ferulate that was approximately $47 \%$ more than that reported for the synthesis of ethyl ferulate in DMSO recently [24]. The obtainable higher yield of isopropyl ferulate in a water-free reaction system supported the potential applications of a silica-immobilized lipase in achieving biocatalysis in organic medium. This approach thus justifies a future framework for the synthesis of various acyl-derivatives of ferulic acid as medically important esters which can be used as prodrugs in pharmaceutical industry.

\section{Acknowledgments}

This work has been funded under a Major Research Project F. no. 34-269/2008 (SR) dated December 30, 2008 awarded to one of the authors (S. S. Kanwar) by University Grants Commission, New Delhi, India, and Department of Biotechnology, Ministry of Science \& Technology, Government of India to Department of Biotechnology, Himachal Pradesh University, Shimla.

\section{References}

[1] S. S. Kanwar, R. K. Kaushal, M. L. Verma et al., "Synthesis of ethyl laurate by hydrogel immobilized lipase of Bacillus coagulans MTCC-6375," Indian Journal of Microbiology, vol. 45, no. 3, pp. 187-193, 2005.

[2] M. L. Verma and S. S. Kanwar, "Lipases," in Wiley Encyclopedia of Industrial Biotechnology: Bioprocess, Bioseparation, and Cell Technology, vol. 5, pp. 3550-3565, 2010.

[3] H. Hirakawa, N. Kamiya, Y. Kawarabayashi, and T. Nagamune, "Log $P$ effect of organic solvents on a thermophilic alcohol dehydrogenase," Biochimica et Biophysica Acta, vol. 1748, no. 1, pp. 94-99, 2005.

[4] S. S. Kanwar, M. Srivastava, S. S. Chimni, I. A. Ghazi, R. K. Kaushal, and G. K. Joshi, "Properties of an immobilized lipase of Bacillus coagulans BTS-1," Acta Microbiologica et Immunologica Hungarica, vol. 51, no. 1-2, pp. 57-73, 2004.

[5] D. L. Compton, "Sunscreens based on vegetable oil," Lipid Technology, vol. 17, pp. 276-279, 2005.
[6] B. Halliwell, "Antioxidant characterization. Methodology and mechanism," Biochemical Pharmacology, vol. 49, no. 10, pp. 1341-1348, 1995.

[7] J. S. Wright, E. R. Johnson, and G. A. DiLabio, "Predicting the activity of phenolic antioxidants: theoretical method, analysis of substituent effects, and application to major families of antioxidants," Journal of the American Chemical Society, vol. 123, no. 6, pp. 1173-1183, 2001.

[8] I. Benoit, D. Navarro, N. Marnet et al., "Feruloyl esterases as a tool for the release of phenolic compounds from agroindustrial by-products," Carbohydrate Research, vol. 341, no. 11, pp. 1820-1827, 2006.

[9] H. Kikuzaki, M. Hisamoto, K. Hirose, K. Akiyama, and H. Taniguchi, "The effect of trans-ferulic acid and gammaoryzanol on ethanol-induced liver injury in C57BL mouse," Journal of Agricultural and Food Chemistry, vol. 50, pp. 21612168, 2002.

[10] E. Graf, "Antioxidant potential of ferulic acid," Free Radical Biology and Medicine, vol. 13, no. 4, pp. 435-448, 1992.

[11] A. F. G. Cicero and A. Gaddi, "Rice bran oil and $\gamma$ oryzanol in the treatment of hyperlipoproteinaemias and other conditions," Phytotherapy Research, vol. 15, no. 4, pp. 277-289, 2001.

[12] T. Akihisa, K. Tasukawa, M. Yamaura et al., "Triterpene alcohol and sterol ferulates from rice bran and their antioxidant properties," Journal of Agricultural and Food Chemistry, vol. 48, pp. 2313-2319, 2000.

[13] M. Reslow, P. Adlercreutz, and B. Mattiasson, "On the importance of the support material for bioorganic synthesis. Influence of water partition between solvent, enzyme and solid support in water-poor reaction media," European Journal of Biochemistry, vol. 177, pp. 313-318, 1988.

[14] A. Zaks and A. M. Klibanov, "Enzymatic catalysis in nonaqueous solvents," Journal of Biological Chemistry, vol. 263, no. 7, pp. 3194-3201, 1988.

[15] T. Nishio, T. Chicano, and M. Kamimura, "Purification and some properties of lipase produced by Pseudomonas fragi," Agricultural and Biological Chemistry, vol. 52, pp. 1203-1208, 1988.

[16] P. Vidinha, N. Harper, N. M. Micaelo et al., "Effect of immobilization support, water activity, and enzyme ionization state on cutinase activity and enantioselectivity in organic media," Biotechnology and Bioengineering, vol. 85, no. 4, pp. 442-449, 2004.

[17] U. K. Winkler and M. Stuckmann, "Glycogen, hyaluronate, and some other polysaccharides greatly enhance the formation of exolipase by Serratia marcescens," Journal of Bacteriology, vol. 138, no. 3, pp. 663-670, 1979.

[18] O. H. Lowry, N. J. Rosenbrough, A. L. Farr, and R. J. Randall, "Protein measurement with the Folin phenol reagent," The Journal of biological chemistry, vol. 193, no. 1, pp. 265-275, 1951.

[19] S. S. Kanwar, M. L. Verma, C. Maheshwari, S. Chauhan, S. S. Chimni, and G. S. Chauhan, "Properties of poly(AAc-coHPMA-cl-EGDMA) hydrogel-bound lipase of Pseudomonas aeruginosa MTCC-4713 and its use in synthesis of methyl acrylate," Journal of Applied Polymer Science, vol. 104, no. 1, pp. 183-191, 2007.

[20] M. J. Hills, I. Kiewitt, and K. D. Mukherjee, "Synthetic reactions catalyzed by immobilized lipase from oilseed rape (Brassica napus L.)," Applied Biochemistry and Biotechnology, vol. 27, no. 2, pp. 123-129, 1991.

[21] S. W. Park, Y. I. Kim, K. H. Chung, and S. W. Kim, "Improvement of stability of immobilized GL-7-ACA acylase through 
modification with glutaraldehyde," Process Biochemistry, vol. 37, no. 2, pp. 153-163, 2001.

[22] J. M. Palomo, R. L. Segura, G. Fernandez-Lorente, R. Fernandez-Lafuente, and J. M. Guisán, "Glutaraldehyde modification of lipases adsorbed on aminated supports: a simple way to improve their behaviour as enantioselective biocatalyst," Enzyme and Microbial Technology, vol. 40, no. 4, pp. 704707, 2007.

[23] H. J. Chae, M. J. In, and E. Y. Kim, "Optimization of protease immobilization by covalent binding using glutaraldehyde," Applied Biochemistry and Biotechnology. Part A, vol. 73, no. 23, pp. 195-204, 1998.

[24] A. Kumar and S. S. Kanwar, "Synthesis of ethyl ferulate in organic medium using celite-immobilized lipase," Bioresource Technology, vol. 102, no. 3, pp. 2162-2167, 2011.

[25] R. G. Jensen, D. R. Galluzzo, and V. J. Bush, "Selectivity is an important characteristic of lipases (acylglycerol hydrolases)," Biocatalysis, vol. 3, pp. 307-317, 1990.

[26] U. T. Bornscheuer, "Lipase-catalyzed syntheses of monoacylglycerols," Enzyme and Microbial Technology, vol. 17, no. 7, pp. 578-586, 1995.

[27] R. R. Klein, G. King, R. A. Moreau, G. P. McNeill, P. Villeneuve, and M. J. Haas, "Additive effects of acyl-binding site mutations on the fatty acid selectivity of Rhizopus delemar lipase," Journal of the American Oil Chemists' Society, vol. 74, no. 11, pp. 1401-1407, 1997.

[28] J. S. Rhee and S. J. Kwon, "Water activity control in lipase-catalyzed reaction system," Journal of Microbiology and Biotechnology, vol. 8, no. 3, pp. 191-196, 1998.

[29] C. H. Lee and K. L. Parkin, "Effect of water activity and immobilization on fatty acid selectivity for esterification reactions mediated by lipases," Biotechnology and Bioengineering, vol. 75, no. 2, pp. 219-227, 2001.

[30] V. Dandavate, J. Jinjala, H. Keharia, and D. Madamwar, "Production, partial purification and characterization of organic solvent tolerant lipase from Burkholderia multivorans V2 and its application for ester synthesis," Bioresource Technology, vol. 100, no. 13, pp. 3374-3381, 2009.

[31] H. Konthanen, M. Tenkanen, R. Fagerstrom, and T. Reinikainen, "Characterization of steryl esterase activities in commercial lipase preprations," Journal of Biotechnology, vol. 108, pp. 51-59, 2004.

[32] M. Tsuchiyama, T. Sakamoto, T. Fujita, S. Murata, and H. Kawasaki, "Esterification of ferulic acid with polyols using a ferulic acid esterase from Aspergillus niger," Biochimica et Biophysica Acta, vol. 1760, no. 7, pp. 1071-1079, 2006.

[33] H. Kontkanen, M. Tenkanen, R. Fagerström, and T. Reinikainen, "Characterisation of steryl esterase activities in commercial lipase preparations," Journal of Biotechnology, vol. 108, no. 1, pp. 51-59, 2004

[34] M. L. Verma, G. S. Chauhan, and S. S. Kanwar, "Enzymatic synthesis of isopropyl myristate using immobilized lipase from Bacillus cereus MTCC 8372," Acta Microbiologica et Immunologica Hungarica, vol. 55, no. 3, pp. 327-342, 2008.

[35] P. J. Halling, "Effects of water on equilibria catalysed by hydrolytic enzymes in biphasic reaction systems," Enzyme and Microbial Technology, vol. 6, no. 11, pp. 513-516, 1984.

[36] S. S. Kanwar, G. S. Chauhan, S. S. Chimni, S. Chauhan, G. S. Rawat, and R. K. Kaushal, "Methacrylic acid and dodecyl methacrylate (MAc-DMA) hydrogel for enhanced catalytic activity of lipase of Bacillus coagulans MTCC-6375," Journal of Applied Polymer Science, vol. 100, no. 2, pp. 1420-1426, 2006.

[37] F. Chamouleau, D. Coulon, M. Girardin, and M. Ghoul, "Influence of water activity and water content on sugar esters lipase-catalyzed synthesis in organic media," Journal of Molecular Catalysis B, vol. 11, no. 4-6, pp. 949-954, 2001.

[38] R. D. Sonwalkar, C. C. Chen, and LU. K. Ju, "Roles of silica gel in polycondensation of lactic acid in organic solvent," Bioresource Technology, vol. 87, no. 1, pp. 69-73, 2003.

[39] R. N. Z. R. A. Rahman, S. N. Baharum, A. B. Salleh, and M. Basri, "S5 lipase: an organic solvent tolerant enzyme," Journal of Microbiology, vol. 44, no. 6, pp. 583-590, 2006.

[40] J. P. Glusker, A. K. Katz, and C. W. Bock, "Metal ions in biological systems," The Rigaku Journal, vol. 16, pp. 8-16, 1999. 

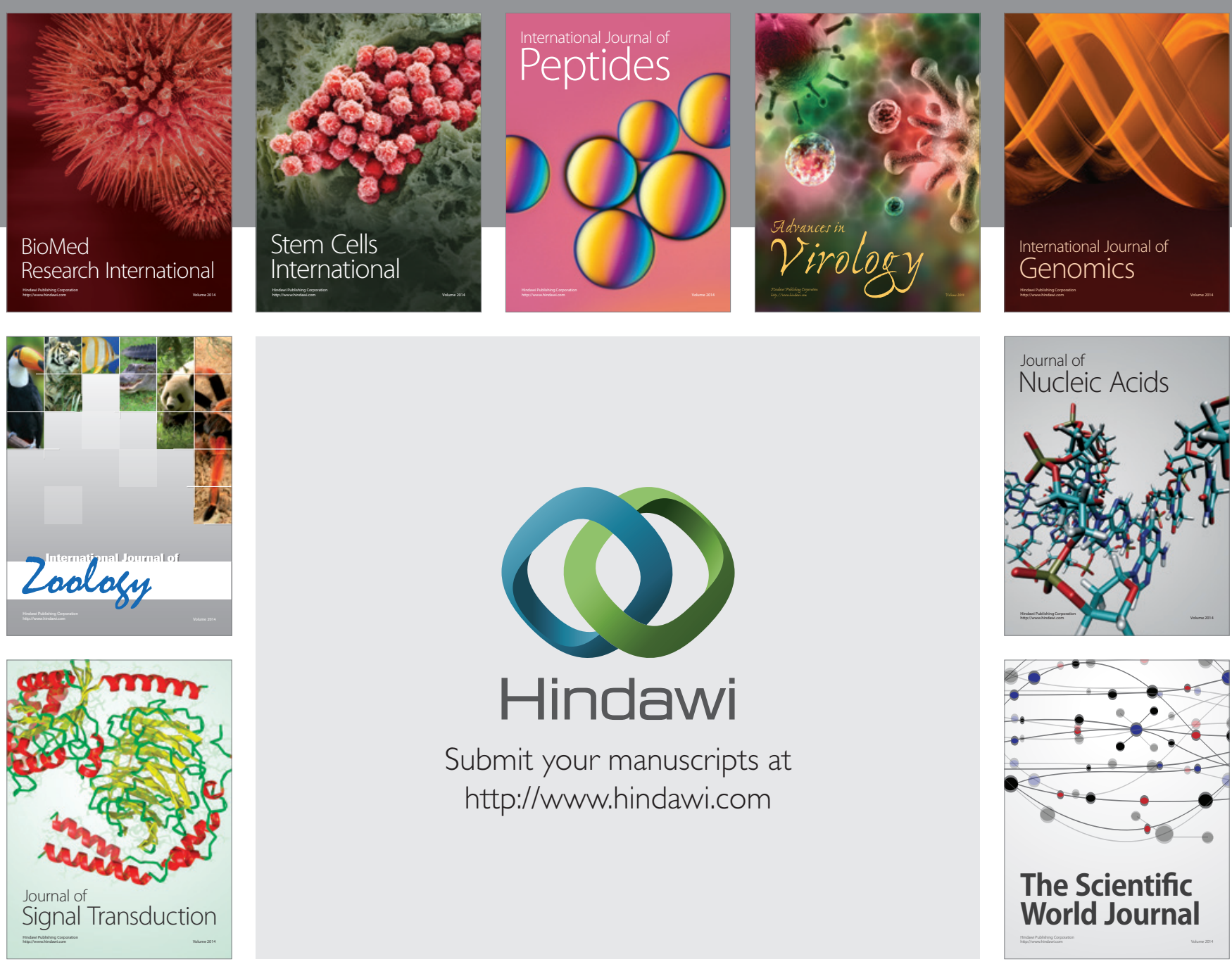

Submit your manuscripts at

http://www.hindawi.com
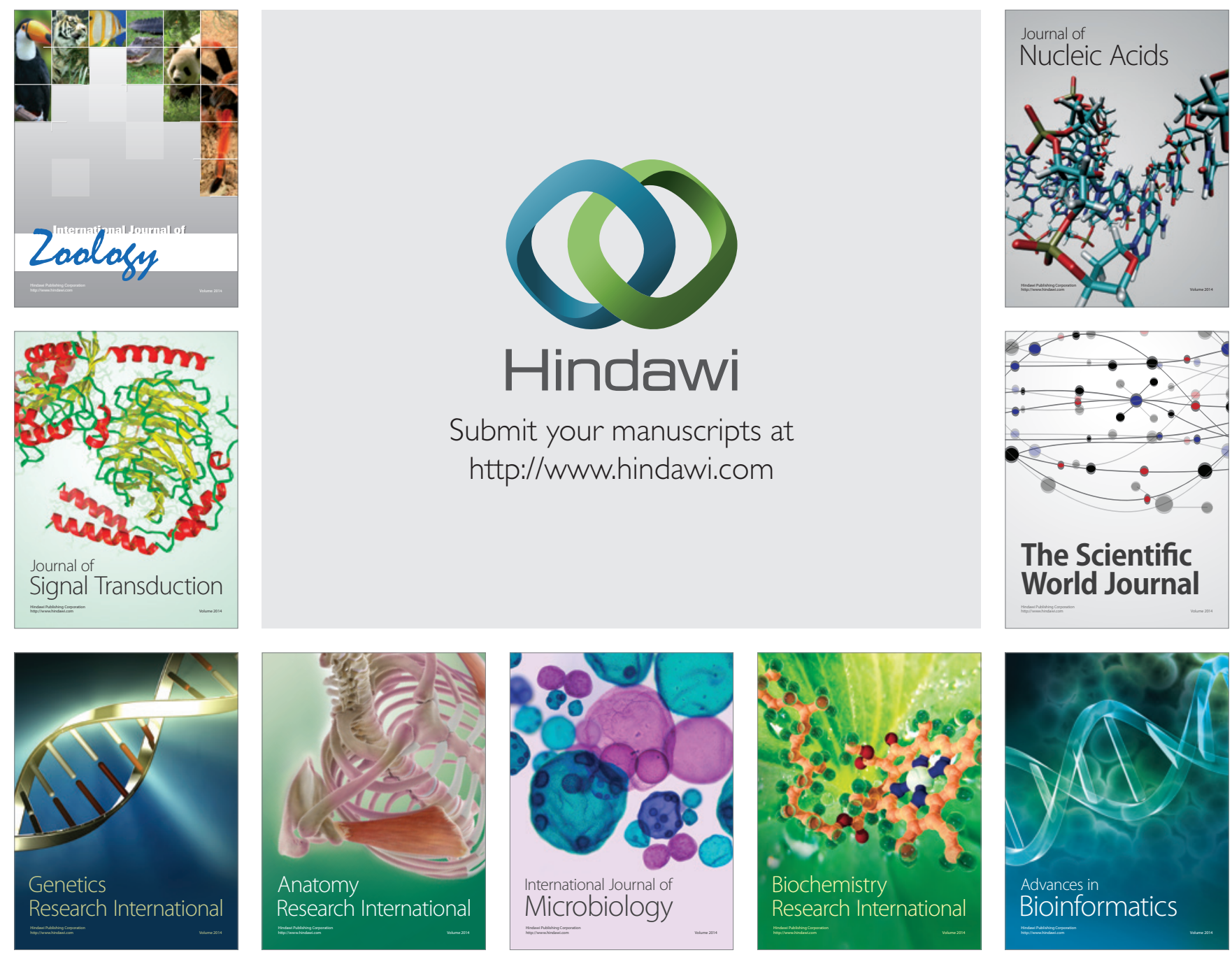

The Scientific World Journal
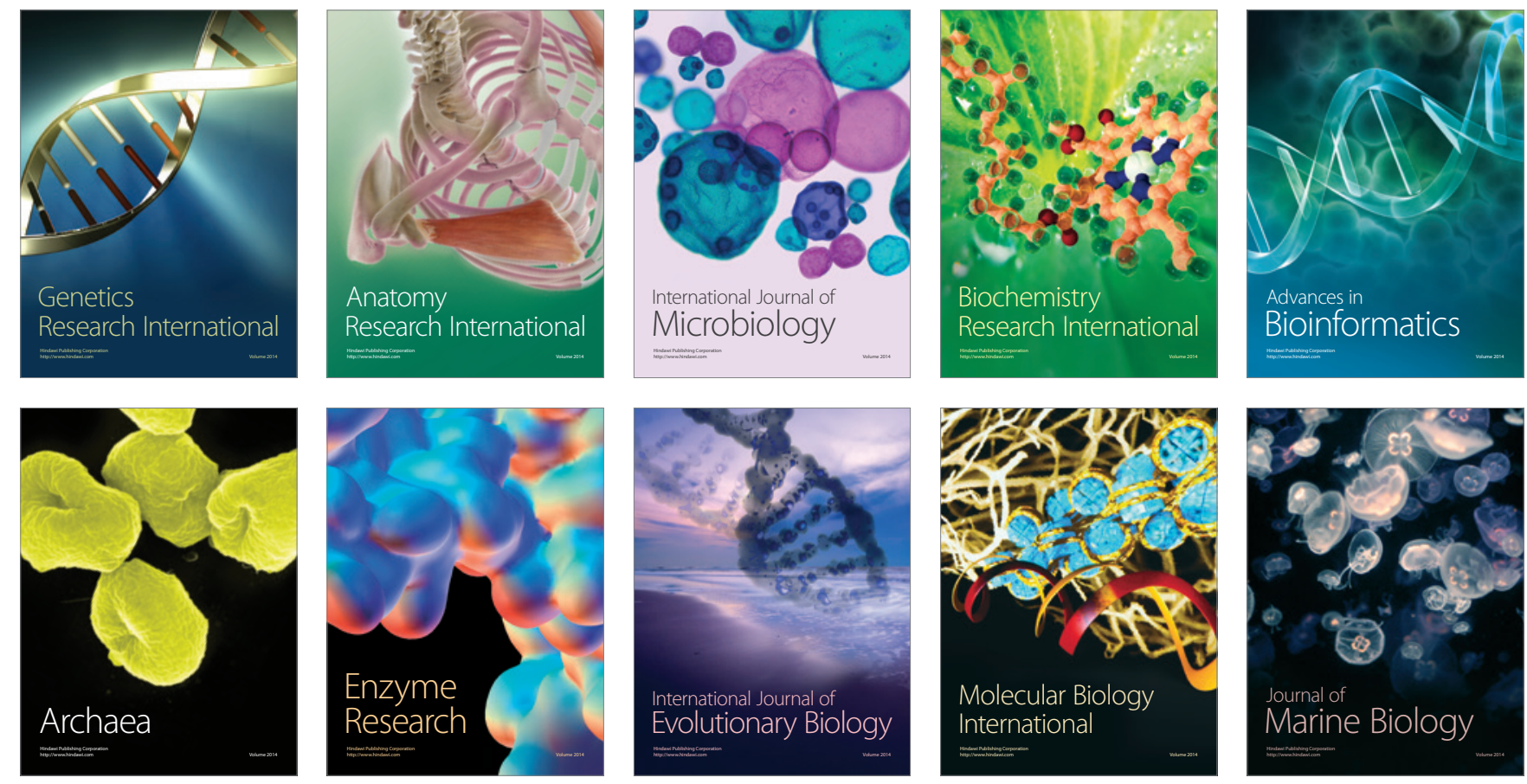